\title{
Prevalence of apple scab and powdery mildew infecting apples in Uganda and effectiveness of available fungicides for their management
}

\author{
Arinaitwe Abel Byarugaba*, Turyamureeba Gard and Imelda Night Kashaija \\ Kachwekano Zonal Agricultural Research and Development Institute, P. O. Box 421, Kabale, Uganda.
}

Accepted 24 April, 2013

\begin{abstract}
Apple scab caused by Venturia inaequalis (Cooke) wint, and apple powdery mildew, caused by Podosphaera leucotricha (EII. and Ev.), are the most important diseases of apples in Uganda. Control of apple scab and powdery mildew require the application of fungicides in absence of resistant apple cultivars. This study was conducted to identify effective control fungicides and to document the status of these diseases in south western Uganda. The survey results of 2012 indicated that scab incidence was highest in districts of Kanungu (71.90\%), followed by Kisoro (48.14\%), Kabale (41.03\%), Buhweju (29.23\%), Mbarara (28.75\%) and Rukungiri (17.80\%). The severity of apple scab measured as percentage leaf area affected ranged from 20.12 to $\mathbf{7 6 . 1 9 \%}$. Powdery mildew incidence ranged from $\mathbf{3 0 . 0 0}$ to $\mathbf{7 0 . 0 0 \%}$ with severity score ranging from 14.63 to $76.19 \%$. Fungicides containing propineb $(70 \%$ a.i), metalazyl $(4 \%$ a.i $)+$ macozeb $(64 \%$ a.i), and bupirimate $(25 \%$ a.i) were found to be effective at controlling apple scab with potential to reduce the disease severity by $61.11,61.11$ and $58.33 \%$, respectively, while fungicides containing bupirimate $(25 \%$ a.i), tebuconazole $(43 \%$ a.i) and propineb $(58 \%$ a.i) + cymoxanil $(4.8 \%$ a.i) were more effective in the control of powdery mildew with potential to reduce the infection by $55.95,39.12$ and $20.84 \%$, respectively.
\end{abstract}

Key words: Apple scab, powdery mildew and fungicides.

\section{INTRODUCTION}

Apple production is new agro enterprise that was established in Uganda since 2000 in South-western highlands mainly in Kabale district (ICRAF, 2003). 13 apple cultivars were introduced by NARO and ICRAF following farmers' demand for fruit trees. Two apple cultivars 'Anna and Golden Dorsett' were officially released in 2009 and are now widely grown in Uganda in the highlands of south western region as commercial varieties. The production of apples however is faced with a number of challenges among which diseases are one of the important constraints facing apple farmers. Apple scab and powdery mildew were identified as the most important diseases of apples in the country, with a potential to cause significant effects on the developing temperate fruit agro enterprise (Chemining et al., 2005). The apple scab pathogen Venturia inaequalis (Cooke) wint and the causal agent of powdery mildew (Podosphaera leucotricha (Ell. and Ev.) cause extensive crop losses in all apple production areas (Kerik, 2012; Brun et al., 2008). In the absence of proven diseases management technologies in Uganda, attempts to control these two diseases have been initiated through the use of fungicides and screening for tolerance among the introduced apple cultivars. However, no proper 
information is currently available regarding appropriate fungicides for the management of apple scab and powdery mildew. Therefore, this study was established to document the status of these diseases in the country and to evaluate the effectiveness of the available fungicides in the control of the diseases at Bungongi substation, in Kabale located at $1830 \mathrm{~m}$ a.s.I so that information on effective fungicides could be released and recommended for farmers to use.

\section{MATERIALS AND METHODS}

\section{Prevalence of apple scab and powdery mildew in western district of Uganda}

A survey was conducted in six district of the Western region of the country, where apples have been established since 2000. The survey districts consisted of Kabale, Kisoro, Kanungu, Rukungiri, Mbarara and Buhweju in western Uganda. Farmers with at least 5 year old apples were purposively selected and identified with help from the Agricultural extension officer. In each apple orchard, apple scab and powdery mildew disease incidence was estimated as percentage of apple tree leaves with visible symptoms. The disease severity was scored as percentage plant leaf area affected (PLAA) with scab according to a scale of 0 to 7 developed by Parisi et al. (1993), Croxall et al. (1952) 0 to 7 where $1=0 \%<$ percentage of scabbed leaf surface (sls)< $1 \% ; 2=1 \%<$ sls $<5 \% ; 3=5 \%<$ sls $<$ $10 \% ; 4=10<$ sls $<25 \% ; 5=25 \%<$ sls $<50 \% ; 6=50 \%<$ sls $<75 \% ; 7=$ $75 \%<$ sls while the severity of powdery mildew was evaluated visually on individual leaflets as percentage of infected area, using a 0 to 4 scale, where 0 : no symptoms; 1 : 1 to $5 \%$; 2 : 5.1 to $20 \%$; 3 : 20.1 to $40 \%$; $4: 40.1$ to $100 \%$ (Kim et al., 2004).

\section{Screening fungicides to control powdery mildew and apple scab}

Commercially available fungicides were evaluated in a nursery of apple rootstocks at Bugongi sub-station, for their efficacy in the control of apple scab and powdery mildew. The chemical fungicides were accessed from importers of Agricultural chemicals in Kampala. Among the fungicide evaluated, contact fungicides that inhibit fungal spore germination comprising of wettable suphur (80\% a.i), Macozeb ( $80 \%$ a.i), and propineb $(70 \%$ a.i), semi-systemic or systemic fungicides that retards spore movement and germination of sporangia that include propineb (58\% a.i) + cymoxanil $(4.8 \%$ a.i), Famoxadone (16.6\% a.i) + cymoxanil $(22.1 \%$ a.i) and Metalazyl (4\% a.i) + Macozeb (64\% a.i), Carbendazim (43\% a.i), copper oxychloride (92\% a.i), Tebuconazole (43\% a.i) and Bupirimate ( $25 \%$ a.i) were used. For each fungicide, the industrial recommended concentration was applied to apple rootstocks grafted with "Anna and Golden Dorsett" that were infected with scab and powdery mildew.

\section{Disease initiation for fungicide effectiveness in disease management}

One-year-old apple seedlings varieties of 'Anna' and 'dorsett' grafted on rootstocks of "bidden fielder" cultivar were used in this experiment. One set of the experimental material was defoliated to $100 \%$, while other was left intact. Both sets of seedlings were inoculated with spores of powdery mildew and apple scab, prepared from infected leaves as described. Infected leaves were collected and immersed in distilled water for four hours. The leaves were then removed, the inoculum filtered, through a $0.2 \mathrm{~mm}$ sieve. The suspensions were adjusted with distilled water and standardized to $1 \times 10^{3}$ conidia per $\mathrm{ml}$ using a hemacytometer and used as a fine mist spray on the seedlings until run off. Inoculation was done in the evening to encourage spore germination and penetration. $48 \mathrm{~h}$ after innoculation, seedlings were subjected to treatments of contact and systemic fungicides. To prevent interplot interference due to fungicide drift; a split plot design was adopted, where fungicides constituted the main plot and apple cultivars, the sub-plots. The main plots (fungicides) were separated from each other with polythene sheeting. For each combination cultivar by fungicide, three replicates were used.

\section{Fungicide effectiveness in scab and powdery mildew management}

Apple scab and powdery mildew incidence and severity were scored on the first ten leaves following inoculation, from 2009 to 2011. Data on the number of leaves with powdery leaf lesions and scab lesion were counted and used to calculate disease incidence, as a proportion of disease-infected leaves. The mean number of powdery mildew lesions and scab lesions per leaf was considered as the measure of disease severity that was used to compute the percentage leaf area affected (PLAA). Apple scab PLAA was estimated using a scale of 0 to 7 , where; $1=: 0 \%<$ percentage of scabbed leaf surface (sls)< $1 \% ; 2=1 \%<$ sls $<5 \%$; $3=5 \%<$ sls $<$ $10 \% ; 4=10<$ sls $<25 \% ; 5=25 \%<$ sls $<50 \% ; 6=50 \%<$ sls $<75 \% ; 7=$ $75 \%<$ sls (Parisi et al., 1993). Powdery mildew percentage of affected area was estimated visually on individual leaflets using a 0 to 4 scale, where 0: no symptoms; 1 : 1 to $5 \%$; 2: 5.1 to $20 \%$; $3: 20.1$ to $40 \%$; 4: 40.1 to $100 \%$ (Kim et al., 2004). Data were recorded 10 days after fungicide sprays, and, every week subsequently for a period of 8 weeks per season. These data generated on the intensity of powdery mildew and scab was used to compute the area under disease progress curve (rAUDPC) using the procedure of Campbell and Madden (1990).

$\operatorname{AUDPC}=\sum_{\mathrm{i}=1}^{\mathrm{n}}\left[\left(\mathrm{xi}_{\mathrm{i}+\mathrm{x}-1}\right) / 2\right][\mathrm{ti-it-1}]$

Where; $x_{i}=$ present disease severity, $x_{i-1}=$ previous disease severity, ti-ti-1 $=$ time difference between two consecutive disease severities

\section{RESULTS AND DISCUSSION}

\section{Prevalence of apple scab and powdery mildew in Southwestern districts of Uganda}

Apple scab and powdery mildew incidence and severity were significantly different $(P=0.05)$. The results of the current work showed a high incidence of apple scab and powdery mildew in the majority of districts surveyed. Scab incidence was highest in Kanungu (71.90\%), followed by Kisoro (48.14\%), Kabale (41.03\%), Buhweju (29.23\%), Mbarara (28.75\%) and Rukungiri (17.80\%) (Table 1 ). The severity of apple scab was also high in all the districts surveyed, except for Rukungiri where the severity rates were of $20.12 \%$, measured as percentage leaf area affected. Scab severity in Kanungu was $76.19 \%$, in Kisoro, $45.00 \%$, Kabale $44.29 \%$, Buhweju $40.38 \%$, Mbarara $33.45 \%$, and Rukungiri, $20.12 \%$. The most damaged plant part were the leaves, this is in 
Table 1. Prevalence of apple scab in the two varieties grown in south western Uganda.

\begin{tabular}{|c|c|c|c|c|c|c|}
\hline \multirow[b]{2}{*}{ District } & \multicolumn{2}{|c|}{ Cultivar Anna } & \multicolumn{2}{|c|}{ Cultivar Golden Dorsett } & \multirow[b]{2}{*}{$\begin{array}{l}\text { Mean scab } \\
\text { incidence }\end{array}$} & \multirow[b]{2}{*}{$\begin{array}{l}\text { Mean scab disease } \\
\text { severity leaf area } \\
\text { affected (PLAA) (\%) }\end{array}$} \\
\hline & $\begin{array}{c}\text { Apple scab } \\
\text { incidence (\%) }\end{array}$ & $\begin{array}{c}\text { Scab disease severity } \\
\text { leaf area affected } \\
\text { (PLAA) (\%) }\end{array}$ & $\begin{array}{c}\text { Apple scab } \\
\text { incidence } \\
(\%)\end{array}$ & $\begin{array}{c}\text { Scab disease severity } \\
\text { leaf area affected } \\
\text { (PLAA) (\%) }\end{array}$ & & \\
\hline Buhweju & 23.33 & 41.67 & 34.29 & 39.29 & 29.23 & 40.38 \\
\hline Kabale & 43.23 & 45.31 & 37.50 & 42.67 & 41.03 & 44.29 \\
\hline Kanungu & 71.82 & 77.27 & 72.00 & 75.00 & 71.90 & 76.19 \\
\hline Kisoro & 47.27 & 44.32 & 49.62 & 46.15 & 48.14 & 45.00 \\
\hline Mbarara & 32.50 & 40.00 & 25.00 & 27.50 & 28.75 & 33.75 \\
\hline Rukugiri & 18.24 & 19.12 & 17.50 & 20.83 & 17.80 & 20.12 \\
\hline Grand Mean & 41.53 & 43.84 & 36.93 & 39.94 & 39.46 & 42.09 \\
\hline F.Pr & & & & & 0.704 & 0.769 \\
\hline $\operatorname{LSD}(P=0.05)$ & & & & & 12.78 & 11.89 \\
\hline
\end{tabular}

agreement with work of Valiuskaite et al. (2009). Powdery mildew disease incidence was highest in Kanungu, at $70.00 \%$, with severity score of $76.19 \%$, followed by Kisoro district, with incidence of $38.00 \%$ and severity score $39.29 \%$, in Kabale mildew incidence was $34.62 \%$ with severity of $41.47 \%$, Buhweju $30.00 \%$ with $39.23 \%$ disease severity, while in Rukungiri incidence of mildew was at $12.93 \%$ with $14.63 \%$ disease severity.

The high incidence and severity of the diseases in most of the districts surveyed is attributed to the lack of proper management practices and lack of knowledge on the appropriate fungicides to be used for the management of these diseases. Developing cultivars resistant to both scab and powdery mildew and use of synthetic fungicides are important for scab and powdery mildew management. In this study it was noted that districts which experience lower temperatures and higher rainfall, scab was a major problem whereas powdery mildew was less important in areas where temperatures are higher and rainfall is lower, powdery mildew is a major problem, and scab is less important. This is supported by report of (Blazek and Hlusickova, 2003). The study also showed no significant difference in infectivity of apple scab and powdery mildew between the two common apple varieties 'Anna' and 'Golden Dorsett' in all the district surveyed (Tables 1 and 2). Cultivars Anna and Golden Dorsett were equally affected by apple scab and powdery mildew in the surveyed district.

\section{Effectiveness of the fungicides for control of powdery mildew and apple scab}

The results of the study indicate a significant difference $(\mathrm{P}=0.05)$ in the effectiveness of fungicides to control powdery mildew for three seasons of the study. Fungicides containing bupirimate $(25 \%$ a.i), Tebuconazole $(43 \%$ a.i) and Propineb (58\% a.i) + cymoxanil $(4.8 \%$ a.i $))$, were more effective in reducing apple disease severity and controlled the development of powdery mildew on leaves and young shoots of apple of grafted apple seedlings. Fungicides containing bupirimate $(25 \%$ a.i) was able to reduce the severity of powdery mildew by $55 \%$, followed by Tebuconazole (43\% a.i) 30\% and Propineb (58\% a.i) + cymoxanil $(4.8 \%$ a.i), 20\%, Copper oxychloride (92\% a.i) $19.54 \%$, Macozeb (80\% a.i) $19.45 \%$, Famoxadone $22.1 \%$ (a.i)+ cymoxanil (30\% a.i) $13.95 \%$, Metalazyl (4\% a.i) + Macozeb (64\% a.i), $10 \%$, Propineb (70\% a.i) $7.79 \%$, and Wettable suphur $(80 \%$ a.i) $5.92 \%$ (Table 3). However, for fungicide Carbendazim (43\% a.i), the intensity of powdery mildew was the same as that of the control (No spray) implying that there was no effect in controlling the disease development

In order to control apple scab, fungicides containing Propineb (70\% a.i), Metalazyl (4\% a.i) + Macozeb (64\% a.i), and bupirimate (25\% a.i) were more effective in controlling apple scab with potential to reduce apple scab severity by 61,61 and $58 \%$, respectively (Table 4). Defoliated apple seedlings exhibit lower disease severity (rAUDPC) for scab across all fungicide sprays, ranging from 0.5 to $5.8 \%$ for defoliated apples, whereas for intact plants, it ranged from 5.1 to $8.5 \%$. This 
Table 2. Prevalence of powdery mildew in the two apple varieties grown in Western Uganda.

\begin{tabular}{|c|c|c|c|c|c|c|}
\hline \multirow[b]{2}{*}{ District } & \multicolumn{2}{|c|}{ Cultivar Anna } & \multicolumn{2}{|c|}{ Cultivar Golden Dorsett } & \multirow[b]{2}{*}{$\begin{array}{c}\text { Mean powdery } \\
\text { mildew } \\
\text { incidence }\end{array}$} & \multirow[b]{2}{*}{$\begin{array}{c}\text { Mean powdery mildew } \\
\text { severityleaf area } \\
\text { affected (PLAA) (\%) }\end{array}$} \\
\hline & $\begin{array}{l}\text { Powdery mildew } \\
\text { incidence (\%) }\end{array}$ & $\begin{array}{c}\text { Powdery mildew } \\
\text { disease severity leaf } \\
\text { area affected (PLAA) (\%) }\end{array}$ & $\begin{array}{c}\text { Powdery } \\
\text { mildew } \\
\text { incidence (\%) }\end{array}$ & $\begin{array}{c}\text { Powdery mildew disease } \\
\text { severity leaf area } \\
\text { affected (PLAA) (\%) }\end{array}$ & & \\
\hline Buhweju & 26.67 & 41.67 & 32.86 & 37.14 & 30.00 & 39.23 \\
\hline Kabale & 35.31 & 42.08 & 33.50 & 40.50 & 34.62 & 41.47 \\
\hline Kanungu & 69.09 & 75.00 & 71.00 & 77.50 & 70.00 & 76.19 \\
\hline Kisoro & 40.00 & 39.77 & 34.62 & 38.46 & 38.00 & 39.29 \\
\hline Mbarara & 20.00 & 43.75 & 12.50 & 25.00 & 16.25 & 34.38 \\
\hline Rukugiri & 20.00 & 22.35 & 7.92 & 9.17 & 12.93 & 14.63 \\
\hline Grand Mean & 36.25 & 41.90 & 29.94 & 34.89 & 33.42 & 38.75 \\
\hline F.pr & & & & & 0.369 & 0.357 \\
\hline $\operatorname{LSD}(\mathrm{P}=0.05)$ & & & & & 11.57 & 12.98 \\
\hline
\end{tabular}

Table 3. Average rAUDPC for powdery mildew and percentage reduction in severity for three seasons, as influenced by different fungicides in apple crops.

\begin{tabular}{|c|c|c|c|c|}
\hline Fungicide trade name & Active ingredient & $\begin{array}{l}\text { Application } \\
\text { rate }\end{array}$ & $\begin{array}{l}\text { Disease severity for powdery } \\
\text { mildew, measured as rAUDPC }\end{array}$ & $\begin{array}{l}\text { \% reduction in powdery mildew } \\
\text { disease severity }\end{array}$ \\
\hline Nimrod & Bupirimate $25 \%$ & $15 \mathrm{~g} / 100 \mathrm{~L}$ & 19.57 & 55.95 \\
\hline Orius & Tebuconazole $43 \%$ & $35 \mathrm{ml} / 100 \mathrm{~L}$ & 27.05 & 39.12 \\
\hline Milraz & Propineb $58 \%$ and cymoxanil $4.8 \%$ & $200 \mathrm{~g} / 100 \mathrm{~L}$ & 35.17 & 20.84 \\
\hline Cobox & Copper oxychloride $92 \%$ & $500 \mathrm{~g} / 100 \mathrm{~L}$ & 35.75 & 19.54 \\
\hline Agrozeb & Macozeb $80 \%$ & $200 \mathrm{~g} / 100 \mathrm{~L}$ & 35.79 & 19.45 \\
\hline Equatin Pro & Famoxadone $22.1 \%$ + cymoxanil 30\%) & $50 \mathrm{~g} / 100 \mathrm{~L}$ & 38.23 & 13.95 \\
\hline Ridomil Gold & Metalazyl 4\% +Macozeb 64\% & $250 \mathrm{~g} / 100 \mathrm{~L}$ & 39.98 & 10.02 \\
\hline Antracol & Propineb $70 \%$ & $200 \mathrm{~g} / 100 \mathrm{~L}$ & 40.97 & 7.79 \\
\hline Thiovit & Wettable suphur $80 \%$ & $200 \mathrm{~g} / 100 \mathrm{~L}$ & 41.8 & 5.92 \\
\hline Rodazim & Carbendazim $43 \%$ & $30 \mathrm{~g} / 100 \mathrm{~L}$ & 47.35 & -6.57 \\
\hline Control & & & 44.43 & \\
\hline Grand Mean & & & 37.58 & \\
\hline F.pr & & & 0.036 & \\
\hline $\operatorname{LSD}(P=0.05)$ & & & 13.77 & \\
\hline
\end{tabular}

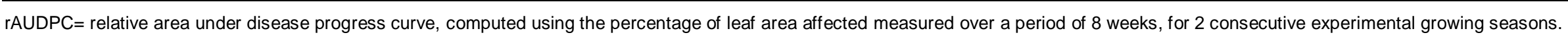


Table 4. Average rAUDPC for apple scab and percentage reduction in the disease severity, for two seasons as influenced by different fungicides.

\begin{tabular}{|c|c|c|c|c|c|c|}
\hline Fungicide trade name & Active ingredient & Application rate & Defoliated & Un defoliated & Grand mean & $\%$ reduction in scab severity \\
\hline Antracol & Propineb $70 \%$ & $200 \mathrm{~g} / 100 \mathrm{~L}$ & 0.5 & 5.1 & 2.8 & 61.11 \\
\hline Ridomil & Metalazyl 4\% +Macozeb 64\% & $250 \mathrm{~g} / 100 \mathrm{~L}$ & 1 & 4.6 & 2.8 & 61.11 \\
\hline Nimrod & Bupirimate $25 \%$ & $15 \mathrm{~g} / 100 \mathrm{~L}$ & 1.4 & 4.6 & 3.0 & 58.33 \\
\hline Cobox & Copper oxychloride $92 \%$ & $500 \mathrm{~g} / 100 \mathrm{~L}$ & 1 & 5.7 & 3.3 & 54.17 \\
\hline Milraz & Propineb $58 \%$ and cymoxanil $4.8 \%$ & $200 \mathrm{~g} / 100 \mathrm{~L}$ & 2.6 & 5.2 & 3.9 & 45.83 \\
\hline Rodazim & Carbendazim $43 \%$ & $30 \mathrm{~g} / 100 \mathrm{~L}$ & 2.5 & 5.2 & 3.9 & 45.83 \\
\hline Agrozeb & Macozeb $80 \%$ & $200 \mathrm{~g} / 100 \mathrm{~L}$ & 2.1 & 9.1 & 5.6 & 22.22 \\
\hline Control & & & 5.8 & 8.5 & 7.2 & - \\
\hline F.pr & & & $<.001$ & $<.001$ & 0.001 & \\
\hline $\operatorname{LSD}(P=0.05)$ & & & 0.98 & 0.98 & 2.19 & \\
\hline
\end{tabular}

indicates that farmers should defoliate their apple orchards prior to fungicide spraying, as this cultural practice helps to reduce the disease innoculum, and subsequent disease severity. Therefore, it is recommended, for effective control of powdery mildew, that the plants are defoliated prior to spraying so that the product can reach newly formed leaves allowing an effective management of the spread of the disease.Based on the results of the current study, it is recommended that fungicide containing propineb (70\% a.i), Metalazyl (4\% a.i)+ Macozeb (64\% a.i), and bupirimate $(25 \%$ a.i) are used for effective management of apple scab, whereas Bupirimate (25\%), Tebuconazole (43\%) and Propineb (58\%) + cymoxanil $(4.8 \%$ a.i), are recommended for the control of powdery mildew in Uganda. The order of the recommendations correspond to the effectiveness of the products in our experimental conditions.

\section{Conclusion}

The interchangeable use of fungicides containing propineb (70\%), Metalazyl 4\% + Macozeb $64 \%)$,and bupirimate (25\%) promotes the contro of apple scab to levels below those causing economic damages. The products of Bupirimate (25\%), Tebuconazole (43\%) and Propineb (58\%) + cymoxanil $(4.8 \%)$ are recommended for the management powdery mildew. Incorporating cultural methods, such as defoliation and use of resistant varieties, could also help to reduce the severity of the investigated diseases.

\section{ACKNOWLEDGEMENTS}

We acknowledge the Government of Uganda and National Agricultural Research Organization for providing funds to conduct the research.

\section{REFERENCES}

Blazek J, Hlusickova I (2003). Influence of climatic conditions on yield $s$ and fruit performance of new apple cultivars from the Czech Republic. Acta. Hort. 622:443-448.

Brun L, Didelot F, Parisi L (2008). Effects of apple cultivar susceptibility to Venturia inaequalis on scab epidemics in apple orchards. Crop Prot. 27(6):1009-1101.

Campbell CL, Madden V (1990). Introduction to disease Epidemiology. John Wiley and sons, New York. P. 532

Chemining WG, Mulagoli I, Mwonga S, Ndubi J, Tum J, Turyamureeba $\mathrm{G}$ (2005). Kabale apples: boom or burst? A study to develop strategies to exploit market opportunities for apple farmers in Kabale, Uganda. pp. 23-24.

Croxall HE, Gwynne DC, Jenkins EE (1952). The rapid assessment of apple scab on leaves. Plant Pathol. 1:39-41.

ICRAF (2003). Temperate fruits go tropical: Apples, peaches, pears and plums take to the hills of Uganda. ICRAF, Nairobi, Kenya.

Kerik DC (2012). Future fungicides for scab/mildew in the face of multiple fungicide resistance. Dept. of Plant Pathology and Plant-Microbe Biology. Cornell University, NYSAES, Geneva, NY 14456.

Kim JC, Choi GJ, Lee SW, Kim JS, Chung KY, Cho KY (2004). Screening extracts of Achyranthes japonica and Rumex crispus for activity against various plant pathogenic fungi and control of powdery mildew. Pest. Manag. Sci. 60:803808. doi: $10.1002 / p s .811$.

Parisi L, Lespinasse Y, Guillaumes J, Kruger J (1993). A new race of Venturia inaequalis virulent to apples with resistance due to the Vf gene. Phytopathology 93:533-537.

Valiuskaite A, Raudonis L, Lanauskas J, Sasnauskas A Surviliene $E$ (2009). Disease incidence on different cultivars of apple tree for organic growing. Agron. Res. 7 (1):536-541. 